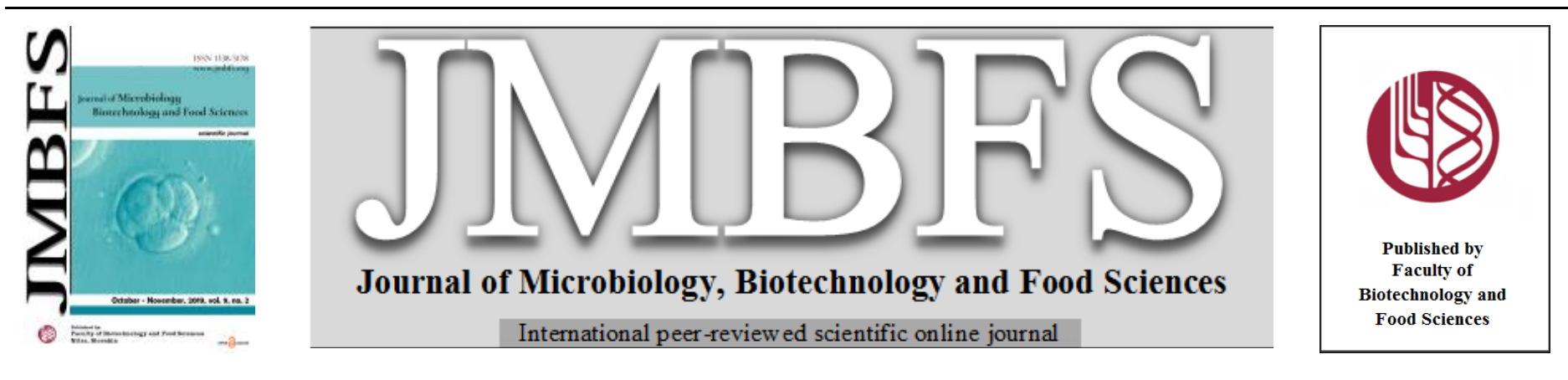

\title{
CHEMICAL COMPOSITION OF MUSCLE AFTER BEE BREAD APPLICATION IN THE NUTRITION OF JAPANESE QUAILS
}

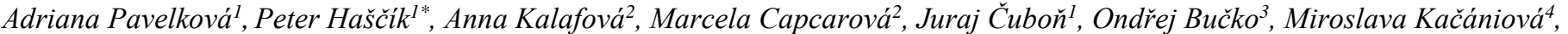 \\ Emília Hanusová ${ }^{5}$, Jana Tkáčovál, Marek Bobko ${ }^{1}$
}

\begin{abstract}
Address(es): doc. Ing. Peter Haščík, PhD.
${ }^{1}$ Slovak University of Agriculture in Nitra, Faculty of Biotechnology and Food Science, Department of Animal Products Evaluation and Processing, Tr. A. Hlinku 2, 94976 Nitra, Slovakia.

${ }^{2}$ Slovak University of Agriculture in Nitra, Faculty of Biotechnology and Food Science, Department of Animal Physiology, Tr. A. Hlinku 2, 94976 Nitra, Slovakia. ${ }^{3}$ Slovak University of Agriculture in Nitra, Faculty of Agrobiology and Food Resources, Department of Animal Husbandry, Tr. A. Hlinku 2, 94976 Nitra, Slovakia.

${ }^{4}$ Slovak University of Agriculture in Nitra, Faculty of Biotechnology and Food Science, Department of Microbiology, Tr. A. Hlinku 2, 94976 Nitra, Slovakia.

${ }^{5}$ National Agricultural and Food Center, Research Institute of Animal Production Nitra, Hlohovecká 2, 95141 Nitra Lužianky, Slovakia.
\end{abstract}

*Corresponding author: peter.hascik@uniag.sk

doi: 10.15414/jmbfs.2020.9.4.831-835

\section{ARTICLE INFO}

Received 27. 3. 2019

Revised 22. 11. 2019

Accepted 4. 12. 2019

Published 3. 2. 2020

Regular article OPEN $\partial_{\text {ACCESS }}$

\begin{abstract}
The objective of study was to evaluate the effects of a diet supplemented with bee bread powder on the chemical composition of Japanese quail meat. A total of 80 one day-old quails were assigned to 4 treatments: 1 . control (C), 2. experimental diet with bee bread (2 g.kg-1 of feed mixture (FM); E1), 3. experimental diet with bee bread (4 g.kg-1 of FM; E2) and 4. experimental diet with bee bread (6 g. $\mathrm{kg}^{-1}$ of FM; E3). The feeding period was 56 days. The supplementation with bee bread improved the protein content of the breast muscle at a dose of 4 a 6 g.kg-1 $\mathrm{FM}\left(25.16\right.$ and $\left.25.25 \mathrm{~g} .100 \mathrm{~g}^{-1}\right)$ versus $\mathrm{C}\left(24.55 \mathrm{~g} .100 \mathrm{~g}^{-1}\right)$. In the thigh muscle, a slightly increased water content in E2 and E3 (70.34 and $\left.70.22 \mathrm{~g} .100 \mathrm{~g}^{-1}\right)$ compared to the $\mathrm{C}\left(69.38 \mathrm{~g} .100 \mathrm{~g} \mathrm{~g}^{-1}\right)$. Bee bread had a beneficial $(\mathrm{P} \geq 0.05)$ effect on the fat in the breast muscle ( $\left.1.18 \mathrm{~g} .100 \mathrm{~g}^{-1} \mathrm{E} 1,1.08 \mathrm{~g} .100 \mathrm{~g} \mathrm{~g}^{-1} \mathrm{E} 2,1.01 \mathrm{~g} .100 \mathrm{~g}^{-1} \mathrm{E} 3\right)$ in comparison to the control $\left(1.21 \mathrm{~g}^{-100 \mathrm{~g}^{-1}}\right)$. The fat content in the thigh muscle increased $(\mathrm{P} \geq 0.05)$ in $\mathrm{E} 1\left(2.01 \mathrm{~g} .100 \mathrm{~g} \mathrm{~g}^{-1}\right)$, E2 $\left(1.76 \mathrm{~g}^{-100 \mathrm{~g}^{-1}}\right)$, E3 $\left(1.76 \mathrm{~g} .100 \mathrm{~g}^{-1}\right)$ when compared to the C $\left(1.30 \mathrm{~g} .100 \mathrm{~g}^{-1}\right)$. Between male and female were observed differences only in the cholesterol content of the breast muscle of the C (female - 0.86 g. $100 \mathrm{~g}^{-1}$, male - $\left.0.72 \mathrm{~g} .100 \mathrm{~g}^{-1}\right)$. Significant differences $(\mathrm{P} \leq 0.05)$ have be also found in the breast muscle in the female with respect to the water, protein, fat and cholesterol content when comparing the $\mathrm{C}$ and $\mathrm{E} 2$, E3. With respect to males we found differences $(\mathrm{P} \leq 0.05)$ in the protein content in the thigh muscle between $\mathrm{E} 1: \mathrm{E} 3, \mathrm{E} 2: \mathrm{E} 3$ and with respect to the fat content between the C and E2. We may state that bee bread powder at 4 , respectively $6 \mathrm{~g}^{\mathrm{kg}} \mathrm{kg}^{-1}$ to the feed mixture could be a suitable supplement to the quail nutrition without a negative effect on the meat quality.
\end{abstract}

Keywords: bee bread; Japanese quail, meat; chemical composition

\section{INTRODUCTION}

During the last decade, the global consumption of poultry meat has increased. Recently, quail meat has gained popularity among consumers (Maiorano et al. 2011). Nowadays, quails may be found on all continents (Genchev et al., 2005). Generally, quails are small-to-medium sized birds, belonging to the same biological family of chicken and pheasants (Phasianidae), given the overall similarity in the physical characteristics and behaviour. Quails, most commonly bred for human consumption, belong to the species Coturnix coturnix japonica (Boni et al., 2010). However, quail provides more advantages than chicken, such as its resistance to numerous poultry diseases that affect chickens, its greater capacity to benefit from food, high reproduction proportions, and also low feed intake (Santos et al., 2011).

The quality and composition of quail meat are influenced by numerous factors such as the genotype of birds (Genchev et al., 2005; Alkan et al., 2010), divergent selection (Maiorano et al., 2009), feeding (Gardzielewska et al., 2005), sex (Genchev et al., 2008), age (Tserveni-Gousi and Yannakopoulos, 1986), and stress (Mota-Rojas et al., 2007).

Manually deboned Japanese quail meat contains $72.5-75.1 \%$ water, 20-23.4\% protein, 1.0-3.4\% lipids and 1.2-1.6\% mineral substances (Genchev et al., 2008; Ribarski et al., 2013). Mechanically deboned quail meat consists of $70.4 \%$ water, $17 \%$ protein, $10 \%$ fat and $2.6 \%$ minerals. The proportion of bone does not exceed $0.75 \%$, with an average diameter of about $0.05 \mathrm{~mm}$ (Antipova and Makarov, 2006). Comparative studies on the physicochemical properties of meat from quails, broiler chicken and ducks demonstrated that quails had the lowestcalorie meat with the highest protein content (Lonita et al., 2008). Choudhary and Mahadevan (1986) state that the protein content in breasts is $23 \%$ versus
$18.7 \%$ in legs. According to the authors such difference is due to different amounts of mineral substances $(1.05 \%$ versus $1.35 \%)$ and lipids $(3.1 \%$ and $5 \%$, respectively). Lipids in the breast and leg muscles are characterized by a value as high as $\mathbf{1 9 . 4 - 5 4 \% ~ o f ~ p o l y u n s a t u r a t e d ~ f a t t y ~ a c i d s ~ ( V r a k i n ~ a n d ~ F o m i n a , ~ 1 9 8 8 ) . ~}$

Antibiotics had been added to poultry feed to improve the growth performance, to stabilize the intestinal microflora and to prevent infection by specific pathogenic microorganisms. However, concerns about the antimicrobial resistance have existed for nearly as long, and recent concerns regarding the prevalence of antibiotic-resistant infections in humans have raised the controversy to new heights (Revington, 2002). For these reasons antibiotic growth promoters for poultry diets have been banned in the European Union and pressure from consumer groups and major poultry buyers has threatened their removal in the US. Therefore, studies on alternative products that could result in the promotion of growth, improved feed utilization, and maintenance of gut health are taking place (Zhang et al., 2005). For this reason, natural bee products are being widely investigated (Babaei et al., 2016; Hašćík et al., 2016, 2017). Bee bread (BB) or ambrosia is a fermented bee product made from plant pollen, honey and bee saliva, which undergoes different chemical processes due to the action of specific enzymes, micro-organisms, moisture and temperature (35-36 ${ }^{\circ} \mathrm{C}$ ) for 2 weeks (Vásquez and Olofsson, 2009; Barajas et al., 2012; Markiewicz-Zukowska et al., 2013; Barene et al., 2014; Fuenmayor et al., 2014; Zuluaga et al., 2015; Kieliszek et al., 2018).

$\mathrm{BB}$ consists primarily of water, proteins, free amino acids, bioactive compounds, fatty acids, and carbohydrates (Del Risco, 2012) and it is the most nutritious food, which is used by worker bees as a source of protein for larvae and for young bees (Urcan et al., 2018). 
BB is characterized by a higher nutritional value, better digestibility, and richer chemical composition than pollen (Habryka, Kruczek and Drygas, 2016) According to the other sources (Gilliam, 1979), the composition of bee bread is biochemically similar to the composition of pollen from which it is produced and like bee pollen, BB is nutritionally well balanced.

Bee bread differs from pollen by a lower $\mathrm{pH}(3.8-4.3)$, it contains less proteins and fats, but more carbohydrates and lactic acid. Bee bread has a better bioavailability because the walls of pollen, which cannot be destructed by gastrointestinal liquids, have been partly processed by fermentation which is why the functionally and energetically rich content of pollen can be assimilated and used easier (Mutsaers et al., 2005; Berene et al., 2014). The chemica composition of pollen is multiform. It contains about $24 \%$ of water and a number of organic and inorganic substances such as proteins, amino acids (glutamic acid, aspartic acid, proline, arginine, valine, histidine, leucine, isoleucine, lysine, methionine, tryptophan, phenylalanine, threonine), carbohydrates (glucose fructose, sucrose, arabinose, galactose, lactose), fats, vitamins (ascorbic acid, thiamine, riboflavin, pyridoxine, pantothenic acid, folic acid, biotin, tocopherol, menaquinones, rutin, niacin), carotenoids, flavonoids, phenolic acids, enzymes (amylase, sucrase, catalase, pectinase, phosphatase), phyto hormones, growing stimulators (auxins, gibberellins), micro and macro elements (potassium, cooper, iron, cobalt, calcium, magnesium, phosphorus, sulfur, silicon, etc.) (Nagai et al., 2004; Berene et al., 2014; Bakour et al., 2017; Kieliszek et al., 2018; Urcan et al., 2018)

The potential application of bee bread as a food and a nutraceutical supplemen greatly depends on its chemical composition which varies directly with the flora of the region and the time of collection by the bees (Čeksterytė et al., 2008, 2016; Markiewicz-Żukowska et al., 2013; Sobral et al., 2017). In the bee bread proteins are partly cleaved to amino acids, fats are destructed, the content of carbohydrates and lactic acid increases, while changes to other components are not significant (Berene et al., 2014)

The activity of pollen (the amount of vitamins and enzymes) decreases after 2 or 3 months of storage. Bee bread keeps its activity longer (Bogdanov, 2011). The biologically active substances present in BB are associated with several medicinal benefits. BB has hepatoprotective, immuno-modulating, antiradiation and adaptogenic properties. It stimulates the protective forces of the human body, normalizes metabolism, has a positive impact on the liver, nervous and endocrine system, and enhances tissue regeneration, physical and mental persistence of the human body (Berene et al., 2014; Bogdanov, 2015). BB helps to regulate lipid metabolism and has also a positive effect on the cardiovascular system (Nagai $\boldsymbol{e}$ al., 2004; Baltrušaityte et al., 2007; Tomás et al., 2017). BB has shown to possess in vitro antibacterial (Baltrušaityte et al., 2007; Zerdani et al., 2011) antioxidant (Nagai et al., 2004; Zuluaga et al., 2015; Tomás et al., 2017) and antitumor (Markiewicz-Zukowska et al., 2013; Sobral et al., 2017) proprieties.

We have hypothesized that meat may exhibit a better chemical composition following dietary supplementation of bee bread powder in quails when compared with quails without supplementation. The present study was therefore carried out to assess the effect of dietary bee bread powder on the chemical composition of quail meat.

\section{MATERIAL AND METHODS}

\section{Animals and diet}

The experiment was carried out in the test poultry station at the Research Institute of Animal Production in Nitra. A total of 80 Japanese quails were included in the experiment. The quails were divided into four groups (10 males and 10 females in each group) as follows: the control group received no additives (C), the experimental group E1 received bee bread powder at a dose of $2 \mathrm{~g}$ per $1 \mathrm{~kg}$ of feed mixture, experimental group E2 $4 \mathrm{~g}$ bee bread powder per $1 \mathrm{~kg}$ of feec mixture and E3 group $6 \mathrm{~g}$ bee bread powder per $1 \mathrm{~kg}$ of feed mixture. Bee bread was of Slovak origin (Medula Ltd., Bratislava). The groups were kept under the same conditions.

The quails were reared using a cage technology, each cage was equipped with a feed disperser and water intake was ensured ad libitum through a self feed-pump up to 56 days of age.

Table 1 list the ingredients and nutrient content of the basal diets (HYD-07, HYD-11), formulated to provide the nutrient requirements of quails according to the recommended reference levels. The feed mixture was produced without any antibiotics and coccidiostats.

Table 1 Composition of basal diet and nutrient content of feed mixtures HYD-07 and HYD-11 per kg of diet.

\begin{tabular}{|c|c|c|}
\hline Ingredients (\%) & $\begin{array}{l}\text { Starter feed mixture (HYD-07) } \\
\left(1^{\text {st }} \text { to } 21^{\text {st }} \text { day }\right)\end{array}$ & $\begin{array}{l}\text { Finisher feed mixture (HYD-11) } \\
\qquad\left(22^{\text {nd }} \text { to } 56^{\text {th }} \text { day }\right)\end{array}$ \\
\hline Wheat & 13 & 15 \\
\hline Maize & 34.8 & 32 \\
\hline Soybean meal (48\% CP) & 23 & 19.2 \\
\hline Fish meal (71\% CP) & 5 & 3 \\
\hline Malt flower & 2 & 3 \\
\hline Rapeseed meal & 5 & 7 \\
\hline Sunflower meal & 5 & 4.5 \\
\hline Monocalcium phosphate & 1 & 1 \\
\hline Fodder salt & 0.2 & 0.3 \\
\hline Animal fat Bergafat & 5 & 4 \\
\hline Calcium carbonate & 5 & 10 \\
\hline Premix Euromix $^{1}$ & 1 & 1 \\
\hline \multicolumn{3}{|c|}{ Analysed composition (g.kg-1) } \\
\hline Crude protein & 245 & 200 \\
\hline Fibre & 50 & 60 \\
\hline Ash & 14 & 16 \\
\hline $\mathrm{Ca}$ & 8 & 35 \\
\hline $\mathrm{P}$ & 6.5 & 5 \\
\hline $\mathrm{Na}$ & 0.9 & 1.6 \\
\hline Lysine & 14.1 & 11 \\
\hline Methionine + Cysteine & 9.5 & 7.9 \\
\hline Linolic acid & 10 & 10 \\
\hline $\mathrm{ME}_{\mathrm{N}}\left(\mathrm{MJ}_{\mathrm{kg}} \mathrm{kg}^{-1}\right)$ & 12.1 & 11.7 \\
\hline
\end{tabular}

Notes: $\mathrm{CP}=$ crude protein $\mathrm{Ca}=$ calcium; $\mathrm{P}=$ phosphorus; $\mathrm{Na}=$ natrium; $\mathrm{ME}_{\mathrm{N}}=$ nitrogen-corrected metabolizable energy; $\mathrm{MJ}=$ megajoule; active substances per kilogram of premix: vitamin A $15000 \mathrm{IU}$; vitamin E $20 \mathrm{mg}$; vitamin D3 $2000 \mathrm{IU}$; riboflavin 6 mg; cobalamin $20 \mu \mathrm{g}$; Mn 60 mg; Zn 40 mg; Fe 40 mg; Cu 6 mg; I 1 mg; Se 0.2 mg.

\section{Slaughter and measurements}

At the end of the 56-d feeding period, twenty quails from each group (10 males, 10 females) were weighed and slaughtered at the slaughterhouse of Slovak University of Agriculture in Nitra. After evisceration, the carcasses were kept at approximately $18{ }^{\circ} \mathrm{C}$ for $1 \mathrm{~h}$ post mortem. After that, the carcasses were weighed and stored at $4{ }^{\circ} \mathrm{C}$ until $24 \mathrm{~h}$ post mortem.

To evaluate the chemical composition skinless breast muscle (musculus pectoralis major) and skinless thigh muscle (musculus biceps femoris) were taken from each group. The chemical composition of meat was rated using the INFRATEC 1265 device (Germany), analysing the water, fat and protein content as well as cholesterol $\left(\mathrm{g} .100 \mathrm{~g}^{-1}\right)$.

\section{Statistical analysis}

The data were analysed using the ANOVA Procedure with the help of the SAS software (version 9.3, by application Enterprise Guide 4.2). Mean values and standard deviation $(S D)$ are reported in tables. Differences between treatments were tested for significance. The level of significance was established at $\mathrm{P} \leq 0.05$.

\section{RESULTS AND DISCUSSION}

The results of experiment are presented as follows: the results of water, crude protein, fat, and cholesterol content in breast and thigh muscle disregarding sex and regarding sex which are displayed in Tables $2-5$. 
In the present study, the water content in the breast muscle (Table 2) of Japanese quails disregarding sex ranged from $69.86 \mathrm{~g} .100 \mathrm{~g}^{-1}$ (experimental group E3) to 70.76 g.100 g $\mathrm{g}^{-1}$ (control group). The highest average value of water content measured in the fresh thigh muscle of quails disregarding sex (Table 3) after addition of the supplements was in the experimental group E2 supplemented with
$4 \mathrm{~g}$ bee bread powder $\left(70.34 \mathrm{~g} .100 \mathrm{~g}^{-1}\right)$ and the lowest value was detected in the control group $\mathrm{C}\left(69.38 \mathrm{~g} .100 \mathrm{~g}^{-1}\right)$. We have found statistically significan differences $(\mathrm{P} \leq 0.05)$ between the control group and experimental groups $\mathrm{E} 2$ and E3.

Table 2 Chemical composition of breast muscle of quails disregarding sex (g.100 g $\left.{ }^{-1}\right)$

\begin{tabular}{lccccc}
\hline Parameter & $\mathbf{C}$ & E1 & E2 & E3 & $p$-value \\
\hline Water content & $70.76 \pm 1.27$ & $70.69 \pm 1.43$ & $70.41 \pm 0.94$ & $69.86 \pm 0.41$ & 0.150 \\
Crude protein & $24.55 \pm 0.16^{\mathrm{c}}$ & $24.67 \pm 0.44^{\mathrm{c}}$ & $25.16 \pm 0.26^{\mathrm{b}}$ & $25.25 \pm 0.27^{\mathrm{a}}$ \\
Fat & $1.21 \pm 0.36$ & $1.18 \pm 0.37$ & $1.08 \pm 0.20$ & $1.01 \pm 0.22$ \\
Cholesterol & $0.79 \pm 0.08$ & $0.83 \pm 0.17$ & $0.69 \pm 0.14$ & $0.71 \pm 0.05$ & 0.307 \\
\hline
\end{tabular}

Notes: Values shown as mean $\pm S D$ (standard deviation); $\mathrm{C}=$ control group; E1, E2, E3 = experimental groups; a, $\mathrm{b}=$ means within a line with different superscripts differ significantly at $\mathrm{P} \leq 0.05$, one-way ANOVA.

Table 3 Chemical composition of thigh muscle of quails disregarding sex $\left(\mathrm{g} .100 \mathrm{~g}^{-1}\right)$

\begin{tabular}{lccccc}
\hline Parameter & C & E1 & E2 & E3 \\
\hline Water content & $69.38 \pm 0.81^{\mathrm{a}}$ & $69.94 \pm 0.45^{\mathrm{ab}}$ & $70.34 \pm 1.40^{\mathrm{b}}$ & $70.22 \pm 0.42^{\mathrm{b}}$ \\
Crude protein & $23.32 \pm 0.18$ & $23.11 \pm 0.42$ & $23.18 \pm 0.44$ & $23.46 \pm 0.30$ \\
Fat & $1.30 \pm 0.30$ & $2.01 \pm 0.75$ & $1.76 \pm 0.69$ & $1.76 \pm 0.36$ \\
Cholesterol & $0.87 \pm 0.05$ & $0.92 \pm 0.04$ & $0.88 \pm 0.18$ & $0.91 \pm 0.06$ \\
\hline
\end{tabular}

Notes: Values shown as mean \pm S.D. (standard deviation); $\mathrm{C}=$ control group; E1, E2, E3 = experimental groups; $\mathrm{a}, \mathrm{b}=$ means within a line with different superscripts differ significantly at $\mathrm{P} \leq 0.05$, one-way ANOVA.

Table 4 Chemical composition of breast muscle of quails regarding sex and group $\left(\mathrm{g} .100 \mathrm{~g}^{-1}\right)$

\begin{tabular}{|c|c|c|c|c|c|c|}
\hline Parameter & sex & $\mathbf{C}$ & E1 & E2 & E3 & $p$-value \\
\hline \multirow[t]{3}{*}{ Water content } & Male & $69.93 \pm 1.27$ & $70.49 \pm 1.19$ & $70.89 \pm 0.79$ & $69.96 \pm 0.59$ & 0.180 \\
\hline & Female & $71.61 \pm 0.56^{\mathrm{a}}$ & $70.88 \pm 1.90^{\mathrm{ab}}$ & $69.93 \pm 0.94^{b}$ & $69.97 \pm 0.17^{b}$ & 0.006 \\
\hline & $p$-value & 0.105 & 0.778 & 0.251 & 0.619 & \\
\hline \multirow[t]{3}{*}{ Crude protein } & Male & $24.49 \pm 0.04$ & $24.60 \pm 0.32$ & $25.07 \pm 0.31$ & $25.16 \pm 0.34$ & 0.077 \\
\hline & Female & $24.62 \pm 0.23^{b}$ & $24.75 \pm 0.61^{\mathrm{ab}}$ & $25.25 \pm 0.23^{\mathrm{a}}$ & $25.34 \pm 0.20^{\mathrm{a}}$ & 0.015 \\
\hline & $p$-value & 0.398 & 0.718 & 0.462 & 0.492 & \\
\hline \multirow[t]{3}{*}{ Fat } & Male & $0.95 \pm 0.37$ & $1.22 \pm 0.55$ & $1.23 \pm 0.19$ & $0.96 \pm 0.34$ & 0.309 \\
\hline & Female & $1.46 \pm 0.06^{\mathrm{a}}$ & $1.15 \pm 0.21^{\mathrm{ab}}$ & $0.94 \pm 0.07^{\mathrm{b}}$ & $1.06 \pm 0.05^{\mathrm{b}}$ & 0.001 \\
\hline & $p$-value & 0.133 & 0.856 & 0.783 & 0.669 & \\
\hline \multirow[t]{3}{*}{ Cholesterol } & Male & $0.72 \pm 0.04^{\mathrm{A}}$ & $0.81 \pm 0.09$ & $0.75 \pm 0.09$ & $0.71 \pm 0.08$ & 0.149 \\
\hline & Female & $0.86 \pm 0.06^{\mathrm{aB}}$ & $0.85 \pm 0.24^{\mathrm{a}}$ & $0.62 \pm 0.17^{\mathrm{b}}$ & $0.70 \pm 0.07^{\mathrm{b}}$ & 0.023 \\
\hline & $p$-value & 0.033 & 0.073 & 0.684 & 0.315 & \\
\hline
\end{tabular}

Notes: Values shown as mean \pm S.D. (standard deviation); $\mathrm{C}=$ control group; $\mathrm{E} 1, \mathrm{E} 2, \mathrm{E} 3=$ experimental groups; $\mathrm{a}, \mathrm{b}=\mathrm{means}$ within a line with different superscripts differ significantly at $\mathrm{P} \leq 0.05 ; \mathrm{A}, \mathrm{B}=$ means within a column with different superscripts differ significantly at $\mathrm{P} \leq 0.05$, one-way ANOVA, t-test.

Table 5 Chemical composition of thigh muscle of quails regarding sex and group $\left(\mathrm{g} .100 \mathrm{~g}^{-1}\right)$

\begin{tabular}{|c|c|c|c|c|c|c|}
\hline Parameter & $\operatorname{sex}$ & $\mathbf{C}$ & E1 & E2 & E3 & $p$-value \\
\hline \multirow[t]{3}{*}{ Water content } & Male & $69.23 \pm 1.24$ & $69.88 \pm 0.49$ & $70.77 \pm 0.93$ & $70.07 \pm 0.27$ & 0.159 \\
\hline & Female & $69.53 \pm 0.25$ & $70.01 \pm 0.52$ & $69.90 \pm 1.87$ & $70.38 \pm 0.55$ & 0.729 \\
\hline & $p$-value & 0.708 & 0.708 & 0.509 & 0.445 & \\
\hline \multirow[t]{3}{*}{ Crude protein } & Male & $23.20 \pm 0.18^{\mathrm{ab}}$ & $23.19 \pm 0.04^{b}$ & $23.08 \pm 0.52^{b}$ & $23.49 \pm 0.13^{\mathrm{a}}$ & 0.019 \\
\hline & Female & $23.45 \pm 0.04$ & $23.04 \pm 0.66$ & $23.28 \pm 0.42$ & $23.43 \pm 0.45$ & 0.406 \\
\hline & $p$-value & 0.085 & 0.750 & 0.640 & 0.855 & \\
\hline \multirow[t]{3}{*}{ Fat } & Male & $1.23 \pm 0.39^{\mathrm{b}}$ & $1.62 \pm 0.19^{\mathrm{ab}}$ & $2.18 \pm 0.40^{\mathrm{a}}$ & $1.65 \pm 0.37^{\mathrm{ab}}$ & 0.041 \\
\hline & Female & $1.38 \pm 0.26$ & $2.41 \pm 0.95$ & $1.33 \pm 0.71$ & $1.86 \pm 0.40$ & 0.144 \\
\hline & $p$-value & 0.598 & 0.232 & 0.145 & 0.538 & \\
\hline \multirow[t]{3}{*}{ Cholesterol } & Male & $0.86 \pm 0.08$ & $0.90 \pm 0.02$ & $0.97 \pm 0.06$ & $0.91 \pm 0.03$ & 0.410 \\
\hline & Female & $0.88 \pm 0.04$ & $0.95 \pm 0.05$ & $0.80 \pm 0.24$ & $0.90 \pm 0.09$ & 0.085 \\
\hline & $p$-value & 0.998 & 0.472 & 0.211 & 0.233 & \\
\hline
\end{tabular}

Notes: Values shown as mean \pm S.D. (standard deviation); $\mathrm{C}=$ control group; E1, E2, E3 = experimental groups; a, $\mathrm{b}=$ means within a line with different superscripts differ significantly at $\mathrm{P} \leq 0.05 ; \mathrm{A}, \mathrm{B}=$ means within a column with different superscripts differ significantly at $\mathrm{P} \leq 0.05$, one-way ANOVA, t-test.

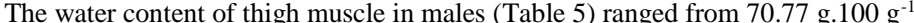
(experimental group E2) to $69.23 \mathrm{~g} .100 \mathrm{~g}^{-1}$ (control group) and in females it ranged from 70.38 g. $100 \mathrm{~g}^{-1}$ (experimental group E3) to $69.53 \mathrm{~g} .100 \mathrm{~g}^{-1}$ (control group). We have not found statistically significant differences $(\mathrm{P} \leq 0.05)$ between males and females as well as between the experimental groups. In case of the quail breast muscle of male and female, the highest measured value of the wate content was in the groups E2 and C (70.89 g.100 g $\mathrm{g}^{-1}$ and $71.61 \mathrm{~g} .100 \mathrm{~g}^{-1}$, respectively) and the lowest value in control group as well as the experimenta group E2, respectively (69.93 g.100 g $\left.\mathrm{g}^{-1}\right)$. We have found statistically significan differences $(\mathrm{P} \leq 0.05)$ between the control group and experimental groups E2 and $\mathrm{E} 3$ in the female quails.

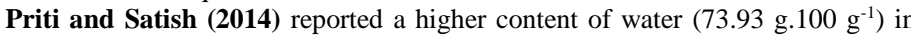
quail meat. Similarly, Genchev et al. (2008) found a higher water content in the breast muscle of 35 day old Japanese quails in males $(72.49 \%$ ) and females $(73.08 \%)$, as well as in case of the thigh muscle $(73.5 \%$ in males and $74.14 \%$ in females).

The highest average value of crude protein content measured in the fresh breast muscle of quails after BB supplementation was found in the experimental group E3 (25.25 g.100 g $\left.\mathrm{g}^{-1}\right)$ and the lowest value was measured in the control group $\mathrm{C}$
(24.55 g.100 g $\left.\mathrm{g}^{-1}\right)$. We found statistically significant differences $(\mathrm{P}<0.05)$ between the control group and experimental groups E2 and E3. In case of fresh thigh muscle the lowest value of crude protein content was detected in the experimenta group E1 (23.11 g.100 g $\left.\mathrm{g}^{-1}\right)$ while the highest value was found in the experimental group E3 (23.46 g.100 g $\mathrm{g}^{-1}$ ). No statistically significant differences were observed $(\mathrm{P}<0.05)$ between the groups.

The crude protein content of thigh muscle in males ranged from $23.08 \mathrm{~g} .100 \mathrm{~g}^{-1}$ (experimental group E2) to $23.49 \mathrm{~g} .100 \mathrm{~g}^{-1}$ (experimental group E3) while in females it varied between $23.04 \mathrm{~g} .100 \mathrm{~g}^{-1}$ (experimental group E1) and 23.45 g.100 $\mathrm{g}^{-1}$ (control group). Statistically significant differences $(\mathrm{P} \leq 0.05)$ were found between the experimental group E3 and experimental groups E1 and E2. In case of quail breast muscle of males and females, the lowest measured value of crude protein content was found in the control group $\mathrm{C}\left(24.49 \mathrm{~g} .100 \mathrm{~g}^{-1}\right.$ and 24.62 g.100 $\mathrm{g}^{-1}$, respectively) while the highest value was detected in the experimental group E3 (25.16 g.100 $\mathrm{g}^{-1}$ and $\left.25.34 \mathrm{~g} .100 \mathrm{~g}^{-1}\right)$. We found statistically significant differences $(\mathrm{P} \leq 0.05)$ between the control and experimental groups E2 and E3 in female quails.

Lisunova et al. (2014) observed 60 days old quails and reported similar results of protein content $\left(25.60 \mathrm{~g} .100 \mathrm{~g}^{-1}\right)$. The results of our study are comparable to 
Fokolade (2015), who revealed that the protein content was significantly higher in the breast muscle ( $\left.24.45 \mathrm{~g} .100 \mathrm{~g}^{-1}\right)$ in comparison to the thigh muscle (18.62 g. $100 \mathrm{~g}^{-1}$ ) of 20 weeks old quails. The protein content in male and female breas muscle (23.38 and $20.49 \mathrm{~g} .100 \mathrm{~g}^{-1}$, respectively) and in male and female thigh muscle (22.23 and $20.91 \mathrm{~g} .100 \mathrm{~g}^{-1}$, respectively) of 35 days old Japanese quails was presented in a study by Genchev et al. (2008). On the other hand, the results of the present study were higher than the values (17.48 to $18.99 \mathrm{~g}^{2} 100 \mathrm{~g} \mathrm{~g}^{-1}$ ) reported by Boni et al. (2010) who compared the meat quality characteristic between young and spent quails as well as those presented by Odunsi and Kehinde (2009) (13.7 and $18.6 \mathrm{~g} .100 \mathrm{~g}^{-1}$ ).

When evaluating the fat content in fresh breast muscle we found the lowest value of $1.01 \mathrm{~g} .100 \mathrm{~g}^{-1}$ in the experimental group E3 with the addition of BB $(6 \mathrm{~g}$ per $\mathrm{kg}$ feed mixture) while the highest average value of $1.21 \mathrm{~g} .100 \mathrm{~g} \mathrm{~g}^{-1}$ was revealed in the control group. The highest value of fat content in the thigh muscle was found in the experimental group E1 (2.01 g.100 g $\left.\mathrm{g}^{-1}\right)$ and the lowest average value $\left(1.30 \mathrm{~g} .100 \mathrm{~g}^{-1}\right)$ the in the control group. No statistically significant differences $(\mathrm{P} \leq 0.05)$ were found in the breast and thigh muscle between groups.

The fat content in the male breast muscle ranged from $0.95 \mathrm{~g} .100 \mathrm{~g}^{-1}$ (control group) to 1.23 g. $100 \mathrm{~g}^{-1}$ (experimental group E2) and with respect to the thigh muscle it ranged from $1.23 \mathrm{~g} .100 \mathrm{~g}^{-1}$ (control group) to $2.18 \mathrm{~g} .100 \mathrm{~g} \mathrm{~g}^{-1}$ (experimental group E2). In the case of the female breast muscle the highest value of fat content was obtained in control group $\left(1.46 \mathrm{~g} .100 \mathrm{~g}^{-1}\right)$ and the lowest $\left(0.94 \mathrm{~g} .100 \mathrm{~g}^{-1}\right)$ in the experimental group E2 while in the thigh muscle, the lowest value (1.33 g.100 g $\mathrm{g}^{-1}$ ) was detected in the experimental group E2 and the highest value was observed in the experimental group E1 $\left(2.41 \mathrm{~g} .100 \mathrm{~g}^{-1}\right)$. We have found statistically significant differences $(\mathrm{P} \leq 0.05)$ in the female breast muscle between the control group and experimental groups E2 and E3 as well as in male thigh muscle between the control group and experimental group E2.

Priti and Satish (2014) reported a higher content of fat $\left(3.85 \mathrm{~g} .100 \mathrm{~g}^{-1}\right)$ when compared with the present results. On the other hand, similar results were published by Genchev et al. (2008) who studied the fat content in the breast muscle (male 2.21 and female $2.75 \mathrm{~g} .100 \mathrm{~g}^{-1}$ ) and in the thigh muscle (male 3.39 and female $3.26 \mathrm{~g} .100 \mathrm{~g}^{-1}$ ). A fat content of $1.28 \%$ in the meat of 60 day old quails was published by Lisunova et al. (2014).

The cholesterol content in quail breast and thigh muscle of the control group was 0.79 and 0.87 g. $100 \mathrm{~g}^{-1}$, while it ranged from $0.69 \mathrm{~g} .100 \mathrm{~g}^{-1}$ (E2) to $0.83{\mathrm{~g} .100 \mathrm{~g}^{-1}}^{-1}$

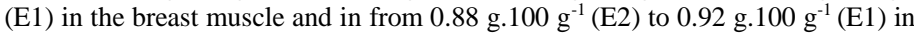
the thigh muscle. No statistically significant differences $(\mathrm{P} \leq 0.05)$ were found. In the case of the cholesterol content in the thigh muscle of male quails, the lowest value was observed in the control group $\left(0.86 \mathrm{~g} .100 \mathrm{~g}^{-1}\right)$ and the highest in the experimental group E2 $\left(0.97 \mathrm{~g} .100 \mathrm{~g}^{-1}\right)$. In the female thigh muscle, the content of cholesterol ranged from $0.80 \mathrm{~g} .100 \mathrm{~g}^{-1}$ (experimental group E2) to $0.95 \mathrm{~g} .100 \mathrm{~g}^{-1}$ (experimental group E1). No statistically significant differences $(\mathrm{P} \leq 0.05)$ were detected.

In the breast muscle of Japanese quails fed with BB the cholesterol content ranged from 0.71 g.100 $\mathrm{g}^{-1}$ (experimental group E3) to $0.81 \mathrm{~g} .100 \mathrm{~g}^{-1}$

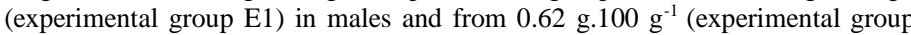
E2) to $0.86 \mathrm{~g} .100 \mathrm{~g}^{-1}$ (control group) in females. We have found statistically significant differences $(\mathrm{P} \leq 0.05)$ in the breast muscle of females between contro group and experimental groups E2 and E3 and we also detected statistically significant differences $(\mathrm{P} \leq 0.05)$ in the control group between the sexes.

Japanese quail meat is characterized by lower cholesterol content when compared to broiler chickens. Maiorano et al. (2011) reported a cholesterol level of pectoralis muscle in quail to vary from 23.57 to $37.20 \mathrm{mg} .100 \mathrm{~g} \mathrm{~g}^{-1}$, which was lower than the cholesterol content found by Maiorano et al. (2009) in the breast muscle of 35 day old Japanese quail (ranging from 27.83 to $43.38 \mathrm{mg} .100 \mathrm{~g} \mathrm{~g}^{-1}$ ) Overall low levels of cholesterol were found in the pectoralis muscle of English White and Manchurian Golden (26.63 and $25.33 \mathrm{mg} .100 \mathrm{~g}^{-1}$, respectively) by Maiorano et al. (2011). Ilavarasan et al. (2016) reported a cholesterol conten of Nandanam Quail-III meat in young and adult quails to be 71.50 and 74.04 mg.100 $\mathrm{g}^{-1}$, respectively. Genchev et al. (2008) observed that the cholestero content in quail carcass was 0.097 and $0.094 \mathrm{~g} .100 \mathrm{~g}^{-1}$ for males and females, respectively.

\section{CONCLUSION}

The present study suggests that dietary supplementation with bee bread powder in quail nutrition improved the content of protein in the breast muscle and slightly increased the water content in the thigh muscle. The feed additive in the bee bread powder form had a beneficial $(\mathrm{P} \geq 0.05)$ effect on a lower fat formation in the breast muscle, but the fat content increased in the experimental groups $(\mathrm{P} \geq 0.05)$ over the control group. In terms of sex, we found fundamental differences $(\mathrm{P} \leq 0.05)$ between the quail male and female within the experimental groups only in the breast muscle with respect to the cholesterol level in the control group. By comparing the sexes among the groups, we have found significant differences $(\mathrm{P} \leq 0.05)$ in the breast muscle only in the quail female in case of the water, protein, fat and cholesterol content between the control group and experimental groups E2 and E3. By contrast, in the thigh muscle by sex and among groups of the experiment, we found significant differences in only quail male in case of the protein content between experimental groups (E1:E3, E2:E3) and in the fat content between the control group and experimental group E2. Since bee bread powder had a clear negative impact on the chemical composition of the breast and thigh muscle of quail, we recommend its administration into the quail diet as a supplementary resource that mainly affects the function of the intestinal microflora and serves to a better utilisation of nutrients affecting the quail growth during the fattening period.

Acknowledgments: This work was supported by [VEGA] under grant [no. 1/0144/19] and [KEGA] [no. 027SPU-4/2019]

\section{REFERENCES}

ALKAN S., KARABAĞ K., GALIC A., KARSLI T., BALCIOĞLU M. S. 2010 Determination of body weight and some carcass traits in Japanese quails (Coturnix coturnix japonica) of different lines. Kafkas Universitesi Veteriner Fakultesi Dergisi, 16(2), 277-280.

ANTIPOVA, L. V., MAKAROV, A. V. 2006. Potential for a broader assortment of functional foods produced from mechanically deboned quail meat Proceedings from the International Scientific Practical Conference on New Trends in Poultry Meat and Eggs Production, VNIIPP State Establishment, October 17-18 $2006(\mathrm{Ru})$.

BABAEI, S., RAHIMI, S., TORSHIZI, M. A. K., TAHMASEBI, G., MIRAN, S N. K. 2016. Effects of propolis, royal jelly, honey and bee pollen on growth performance and immune system of Japanese quails. Veterinary Research Forum, 7(1), 13-20.

BAKOUR, M., AL-WAILI, N. S., EL MENYIY, N., IMTARA, H., FIGUIRA, A.C., AL-WAILI, T., LYOUSSI, B. 2017. Antioxidant activity and protective effect of bee bread (honey and pollen) in aluminum-induced anemia, elevation of inflammatory makers and hepato-renal toxicity. Journal of Food Science and Technology, 54(13), 4205-4212. https://doi.org/10.1007/s13197-017-2889-9

BALTRUŚATTYTĖ, V., VENSKUTONIS, P. R., ČEKSTERYTĖ, V. 2007. Radical Scavenging Activity of Different Floral Origin Honey and Beebread Phenolic Extracts. Food Chemistry, 101(2), 502-514. https://doi.org/10.1016/j.foodchem.2006.02.007

BARAJAS, J., CORTES-RODRIGUEZ, M., RODRÍGUEZ-SANDOVAL, E. 2012. Effect of temperature on the drying process of bee pollen from two zones of Colombia. Journal of Food Process Engineering, 35(1), 134-148. https://doi.org/10.1111/j.1745-4530.2010.00577.x

BARENE, I., DABERTE, I., SIKSNA, S. 2014. Investigation of Bee Bread and Development of Its Dosage Forms. Medicinos teorija ir praktika, 21(1), 16-22. https://doi.org/10.15591/mtp.2015.003

BOGDANOV, S. 2015. Pollen: Production, Nutrition and Health: A Review. Bee Product Sciences, 10, 1-35. Available at: http://www.beehexagon.net/files/file/fileE/Health/PollenBook2Review.pdf

BOGDANOV, S. 2011. Functional and biological properties of the bee products a review. Bee Product Science www.bee-hexagon. net, [cited 2019 January 15]. Available from: URL: http://www.beehexagon.net/files/file/fileE/Health/BeeProductsFunctional.pdf.

BONI, I., NURUL, H., NORYATI, I. 2010. Comparison of meat quality characteristics between young and spent quails. International Food Research Journal, 17(3), 661-667.

ČEKSTERYTÉ, V., KURTINAITIENĖ, B., VENSKUTONIS, P. R., PUKALSKAS, A., KAZERNAVIČIŪTĖ, R., BALŽEKAS, J. 2016. Evaluation of Antioxidant Activity and Flavonoid Composition in Differently Preserved Bee Products. Czech Journal of Food Sciences, 34(2), 133-142. https://doi.org/10.17221/312/2015-cjfs

ČEKSTERYTĖ, V., RAČYS, J., KAŠKONIENĖ, V., VENSKUTONIS, P. R 2008. Fatty acid composition in beebread. Biologija, 54(4), 253-257. https://doi.org/10.2478/v10054-008-0052-2

DEL RISCO, C., PÉREZ, A., ÁlVAREZ, V., RODRÍGUEZ, G., LEIVA, V. PUIG, Y., GARCÍA, R. 2012. Lactic acid bacteria to silage bee pollen. Revista CENIC Ciencias Biológicas, 43, 17-21.

FAKOLADE, P. O. 2015. Effect of Age on Physico-chemical, cholesterol and proximate composition of chicken and quail meat. African Journal of Food Science, 9(4), 182-186. https://doi.org/10.5897/ajfs2015.1282

FUENMAYOR, B., ZULUAGA, D., DÍAZ, M., QUICAZÁN DE, C.,M., COSIO, M., MANNINO, S. 2014. Evaluation of the physicochemical and functional properties of Colombian bee pollen. Revista MVZ Córdoba, 19(1), 4003-4014. https://doi.org/10.21897/rmvz.120

GARDZIELEWSKA, J., JAKUBOWSKA, M., TARASEWICZ, Z. SZCZERBIŃSKA, D., LIGOCKI, M. 2005. Meat quality of broiler quail feed on feeds with different protein content. Electronic Journal of Polish Agricultural Universities. Series Animal Husbandry, 8(1).

GENCHEV A. G., RIBARSKI, S. S., AFANASJEV, G. D., BLOHIN, G. I. 2005 Fattening Capacities And Meat Quality Of Japanese Quails Of Faraon And White English Breeds. Journal Central European of Agriculture, 6(4), 495-500.

GENCHEV, A., MIHAYLOVA, G., RIBARSKI, S., PAVLOV, A. KABAKCHIEV, M. 2008. Meat Quality And Composition In Japanese Quails. Trakia Journal of Sciences, 6(4), 72-82. 
GILLIAM, M. 1979. Microbiology of pollen and bee bread: The yeasts. Apidologie, 10(1), 43-53.

HABRYKA, C., KRUCZEK, M., DRYGAS, B. 2016. Bee products used in apitherapy. World Scientific News, 48, 254-258.

HAŠČÍK, P., TREMBECKÁ, L., BOBKO, M., ČUBOŇ, J., KAČÁNIOVÁ, M., TKÁČOVÁ, J. 2016. Amino acid profile of broiler chickens meat fed diets supplemented with bee pollen and propolis. Journal of Apicultural Research, 55(4), 324-334. http://dx.doi.org/10.1080/00218839.2016.1245398

HAŠČÍK, P., PAVELKOVÁ, A., BOBKO, M., TREMBECKÁ, L., ELIMAM, I O. E., CAPCAROVÁ, M. 2017. The effect of bee pollen in chicken diet. World's Poultry Science Journal, 73(3), 643-650. https://doi.org/10.1017/S0043933917000435

CHOUDHARY M., MAHADEVAN, T. 1986. Influence of age, storage and type of cuts on the composition of quail meat. Indian of Poultry Science, 21(3), 252 254.

ILAVARASAN, R., ABRAHAM ROBINSON, J. J., APPA RAO, V. 2016. The Relationship Between Meat Quality Characteristics and Nutritional Composition of Nandanam Quail-III Slaughtered at Different Ages. Journal of Animal Research, 6(2), 275. https://doi.org/10.5958/2277-940x.2015.00174.6

KIELISZEK, M., PIWOWAREK, K., KOT, A. M., BŁAŻEJAK, S., CHLEBOWSKA-ŚMIGIEL, A., WOLSKA, I. 2018. Pollen and bee bread as new health-oriented products: A review. Trends in Food Science \& Technology, 71, 170-180. https://doi.org/10.1016/j.tifs.2017.10.021

LISUNOVA, L. I., TOKAREV, V. S., GORBACHENKO, YU. V. 2014. AgeRelated Changes in Quail Meat. Russian Agricultural Sciences, 40(2), 146-148. https://doi.org/10.3103/s1068367414020153

LONITA, L., POPESCU-MICLOSANU, E., ROIBU C., CUSTURA, I. 2008 Bibliographical study regarding the quails meat quality in comparison to the chicken and duck meat. Lucrari Stiintifice, 56, 224-229.

MAIORANO, G., ELMINOWSKA-WENDA, G., MIKA, A., RUTKOWSKI, A., BEDNARCZYK, M. 2009. Effects of selection for yolk cholesterol on growth and meat quality in Japanese quail (Coturnix coturnix japonica). Italian Journal of Animal Science, 8(3), 457-466. https://doi.org/10.4081/ijas.2009.457

MAIORANO G., KNAGA S., WITKOWSKI A., CIANCIULLO D. BEDNARCZYK M. 2011. Cholesterol content and intramuscular collagen properties of Pectoralis superficialis muscle of quail from different genetic groups. Poultry Science, 90(7), 1620-1626. https://doi.org/10.3382/ps.2010$\underline{01190}$

MARKIEWICZ-ŻUKOWSKA, R., NALIWAJKO, S. K., BARTOSIUK, E. MOSKWA, J., ISIDOROV, V., SOROCZYŃSKA, J., BORAWSKA, M. H. 2013. Chemical composition and antioxidant activity of beebread, and its influence on the glioblastoma cell line (U87MG). Journal of Apicultural Science, 57(2), 147-157. https://doi.org/10.2478/jas-2013-0025

MOTA-ROJAS, D., GONZÁleZ, V. A., ROJAS, G. E., AGUILERA, A. E., FLORES-PEINADO, S. C., LEMUS-FLORES, C., OLMOS-HERNÁNDEZ, A. BECERRIL-HERRERA, M., CARDONA-LEIJA, A., ALONSO-SPILSBURY, M., RAMIREZ-NECOECHEA, R. 2007. Effect of Heat Stress During Transport and Rest Before Slaughter, on the Metabolic Profile, Blood Gases and Meat Quality of Quail. International Journal of Poultry Science, 6(6), 397-402. https://doi.org/10.3923/ijps.2007.397.402

MUTSAERS, M., BLITTERSWIJK, H., LEVEN, L., KERKVLIET, J., WAERDT, J. 2005. Agrodok 42: Bee products: properties, processing and marketing. Wageningen: Agromisa Foundation; 29-35.

NAGAI, T., NAGASHIMA, T., MYODA, T., INOUE, R. 2004. Preparation and functional properties of extracts from bee bread. Nahrung/Food, 48(3), 226-229. https://doi.org/10.1002/food.200300421

ODUNSI, A. A., KEHINDE, M. O. 2009. Influence of Sex on Carcass and Organoleptic Characteristic of meat from Japanese quails. Processing of $14^{\text {th }}$ Annual Conference of Animal Science Association of Nigeria (ASAN), 226-231. PRITI, M., SATISH, S. 2014. Quail Farming: An Introduction. International Journal of Life Sciences, 2(2), 190-193.

REVINGTON, B. (2002). Feeding poultry in the post-antibiotic era. Multi-State Poultry Meeting, May 14-16. pp. 1-14.

RIBARSKI, S., GENCHEV, A. ATANASOVA, S. 2013. Effect of cold storage terms on physico-chemical characteristics of Japanese quail (Coturnix coturnix japonica) meat. Agricultural Science and Technology, 5(1), 126-133.

SANTOS, T. C., MURAKAMI, A. E., FANHANI, J. C., OLIVEIRA, C. A. L. 2011. Production and reproduction of egg- and meat-type quails reared in different group sizes. Revista Brasileira de Ciência Avicola, 13(1), 9-14 https://doi.org/10.1590/s1516-635x2011000100002

SAS. 2008. 9.3 Enhanced Logging Facilities. Cary, NC: SAS Institute Inc.

SOBRAL, F., CALHELHA, R. C., BARROS, L.; DUEÑAS, M., TOMÁS, A., SANTOS-BUELGA, C., FERREIRA, I. C. 2017. Flavonoid composition and antitumor activity of bee bread collected in northeast Portugal. Molecules, 22(2), 248. https://doi.org/10.3390/molecules 22020248

TOMÁS, A., FALCÃO, S. I., RUSSO-ALMEIDA, P., VILAS-BOAS, M. 2017. Potentialities of Beebread as a Food Supplement and Source of Nutraceuticals: Botanical Origin, Nutritional Composition and Antioxidant Activity. Journal of Apicultural Research, 56(3), 219-230. https://doi.org/10.1080/00218839.2017.1294526
TSERVENI-GOUSI, A. S., YANNAKOPOULOS, A. L. 1986. Carcass characteristics of Japanese quail at 42 days of age. British Poultry Science, 27(1), 123-127. https://doi.org/10.1080/00071668608416863

URCAN, A. CR., CRISTE, A. D., DEZMIREAN, D. S., MARGAOAN, R., CAEIRO, A., CAMPOS, M. G. 2018. Similarity of Data from Bee Bread with the Same Taxa Collected in India and Romania. Molecules, 23(10), 2491. https://doi.org/10.3390/molecules23102491

VÁSQUEZ, A., OLOFSSON, T. C. 2009. The Lactic Acid Bacteria Involved in the Production of Bee Pollen and Bee Bread. Journal of Apicultural Research, 48(3), 189-195. https://doi.org/10.3896/ibra.1.48.3.07

VRAKIN, V., FOMINA, M. 1988. Fatty acid content in breast and leg's meat of the Japanese quails, depending from the age. Biology and technology methods for intensifi cation of poultry breeding, 106-112 (Ru).

ZERDANI, I., ABOUDA, Z., KALALOU, I. FAID, M. AHAMI, M. T. 2011 The antibacterial activity of Moroccan bee bread and bee-pollen (fresh and dried) against pathogenic bacteria. Research Journal of Microbiology, 6(4), 376-384 https://doi.org/10.3923/jm.2011.376.384

ZHANG, K.Y., YAN, F., KEEN, C. A., WALDROUP, P. W. 2005. Evaluation of microencapsulated essential oils and organic acids in diets for broiler chickens. International Journal of Poultry Science, 4(9), 612-619. https://doi.org/10.3923/ijps.2005.612.619

ZULUAGA, C., SERRATO, J. C., QUICAZAN, M. 2015. Chemical, nutritional and bioactive characterization of colombian beebread. Chemical Engineering Transactions, 43, 175-180. http://www.aidic.it/cet/15/43/030.pdf 